\section{Long-term outcome of precommercial thinning on floristic diversity in north western New Brunswick, Canada}

\author{
Cole $H A^{*(1)}$, Newmaster SG ${ }^{(2)}$, Lanteigne $L^{(3)}$, Pitt $D^{(4)}$
}

The Green River spacing trials were established between 1959 and 1961 to study the long-term growth and development of balsam fir (Abies balsamea (L.) Mill.) and red spruce (Picea rubens Sarg.) in response to precommercial thinning (PCT). Three nominal spacings $(1.2 \mathrm{~m}, 1.8 \mathrm{~m}, 2.4 \mathrm{~m})$ and an unthinned control were applied in a randomized complete block design with 5 replicates to regenerating stands, an average of 8 years after harvest. Our study examines floristic diversity associated with these treatments approximately four decades later. Floristic diversity was assessed with several alpha diversity indices as well as multivariate analysis to compare community composition. Specific a-priori contrasts compared plant diversity among a) control and average of the wider spacings $(1.8 \mathrm{~m}$ and $2.4 \mathrm{~m})$, b) control and the narrowest spacing $(1.2 \mathrm{~m})$, and $\mathrm{c})$ the narrowest spacing and the widest spacing. Our results indicate that there were no appreciable differences among the treatments across all measures of plant diversity investigated. As such, we conclude that the forest understory, as represented by the unthinned plots, was analogous in the thinned plots at time of stand maturity. Vegetation response to PCT treatments is inconsistent in the published literature, but this can be attributed to differences in thinning intensities, recovery age or the type of forest ecosystem studied. We conclude that PCT is a variable silvicultural tool that could be used to attain both economic productivity and biodiversity conservation goals.

Keywords: biodiversity, forest ecology, precommercial thinning, silviculture, tree spacing, plant diversity

\section{Introduction}

Modern forest management practitioners are increasingly taking forest diversity into consideration. Consideration should be given for the trade-off between past silviculture practices, which almost exclusively aimed to promote the growth of crop species (Curtis

\footnotetext{
(1) Swiss Federal Research Institute WSL, Biodiversity and Conservation Biology, Zürcherstr. 111, CH-8903, Birmensdorf (Switzerland); (2) Floristic Diversity Research Group, OAC Herbarium, University of Guelph, Guelph, N1G 2W1 - Ontario, (Canada); ${ }^{(3)}$ Canadian Forest Service, Atlantic Forestry Centre, Hugh John Fleming Forestry Centre, P.O. Box 4000, E3B 5P7 Fredericton, New Brunswick (Canada); ${ }^{(4)}$ Canadian Forest Service, Great Lakes Forestry Centre, 1219 Queen St. E., Sault Ste. Marie, P6A 5M7 - Ontario (Canada)
}

*Corresponding Author: Heather Cole (heather.cole@wsl.ch).

Received: Oct 02, 2008 - Accepted: Nov 13, 2008

Citation: Cole HA, Newmaster SG, Lanteigne L, Pitt D, 2008. Long-term outcome of precommercial thinning on floristic diversity in north western New Brunswick, Canada. iForest 1: 145-156 [online: 2008-11-25] URL: http://www.sisef.it/iforest/
\& Carey 1996, Curtis et al. 1997) and the contemporary silviculture goals of managing ecosystems and sustaining biodiversity (Kremsater \& Bunnell 1998, Larsson \& Danell 2001). A reasonable goal is to have the floristic diversity in a managed stand comparable to the diversity in a natural or unmanaged stand of similar age and in comparable environmental conditions (Aubert et al. 2003, Newmaster et al. 2006). The prospective tools for restoration include treatments that favour the composition and structure of the desired crop species, with the expectation that other components of biodiversity will follow (Ramovs \& Roberts 2003, Vallauri et al. 2002). Although precommercial thinning is a common silvicultural tool, the effects of tree species and spacing on the restoration of biodiversity have largely remained untested (Newmaster et al. 2006, Okland et al. 2003, Spence 2001).

Precommercial thinning (PCT) is widely used to manipulate tree species composition and spacing for the purpose of accelerating natural forest succession and growth (Smith 1986). As such, PCT could be used as a tool to restore biodiversity in forest maturity. A strategy aiming to maximize forest productivity by means of PCT treatments could contribute to, maintain, or even increase stand- and forest-level community diversity, and thus help restore forest plant diversity (Jobidon et al. 2004, Vallauri et al. 2002). PCT is used extensively in eastern North America as a means of reducing the density of young conifer stands that have developed from prolific natural regeneration (Pitt \& Lanteigne 2008). Approximately 2 million hectares of young forests have been precommercially thinned from Ontario eastward in Canada during the past 15 years, and efforts continue in this region at a rate approaching 200 thousand hectares per year (CCFM 2005).

Despite its wide use, the effects of PCT on the local floristic diversity are not clear in the published literature. In general, responses of species diversity to forest management are often assumed to be negative (Gilliam \& Roberts 1995). Specific responses to PCT treatments are inconsistent, and range from increased diversity (Lindgren et al. 2006, Thysell \& Carey 2000) to decreased diversity (Thomas et al. 1999, Jobidon et al. 2004, Hansen et al. 1991, Elliott et al. 1997), to similar levels of diversity (Moola \& Vasseur 2004, Kern et al. 2006, He \& Barclay 2000, Berger \& Puettmann 2000, Thomas et al. 2001), compared with unmanaged stands. Many of these studies are based on relatively short-term observations (e.g., < 20 years after thinning), or larger than typically applied spacings (Newmaster et al. 2006). It is not clear whether these effects would still be evident in the longer term (e.g., after treated stands enter the stem exclusion stage - He \& Barclay 2000, Lindgren et al. 2006), or if operational spacings (1.8 to $2.4 \mathrm{~m}$ ) had been used. Further research is needed to clarify the numerous conflicting claims in the literature.

There are few long term research (LTR) spacing trials in North America which could provide an opportunity to test the restoration of native forest biodiversity. The Green River spacing trials, installed between 1959 and 1961 (Baskerville 1959, Baskerville 1961, Akerley 1961) in northwestern New Brunswick by the Canadian Forest Service (previously the Department of Forestry), represent the oldest known, replicated PCT experiments in eastern North America. The Green River trials are particularly relevant to today's growth and yield needs because they encompass typical operational thinning intensities and intervention times (Pitt \& Lanteigne 2008). Although the effects of the Green River experiment on growth and yield have been published (Ker 1981, Ker 1987, Pitt \& Lanteigne 2008), the response of understory plant species to the treatments has received no attention to date. The Green River thinning trials therefore provide a unique opportunity for the study of long term 
effects on plant diversity.

Our study examines the response of floristic plant diversity to the PCT treatments of the Green River LTR trial four decades after thinning, or approximately five decades post-harvest. Floristic diversity was assessed by comparing the thinning treatments (unthinned control, $1.2 \mathrm{~m}, 1.8 \mathrm{~m}$, and $2.4 \mathrm{~m}$ spacing) for alpha diversity (richness, abundance, Simpson's index, Shannon's index, Brillouin's index and Pielou's index) and beta diversity (community ordination analyses). Specific a priori contrasts compared plant diversity among a) control and average of the wider spacings (1.8 $\mathrm{m}$ and $2.4 \mathrm{~m}), \mathrm{b}$ ) control and the narrowest spacing $(1.2 \mathrm{~m})$, and c) the narrowest spacing and the widest spacing.

\section{Methods}

\section{Study area}

The study area is located in the Green River watershed of northwestern New Brunswick, approximately $48 \mathrm{~km}$ north of the town of Edmundston (Baskerville et al. 1960). This region is classified by Rowe (1972) as the Gaspe section (B.2) of the Boreal Forest Region, and by Loucks (1962) as the Green River Site District of the Gaspé-Cape Breton Ecoregion. Topography is strongly rolling, with occasional steep areas. Elevations range between 300 and 450 $\mathrm{m}$. Soils are predominantly stony loams and silt-loams derived from underlying Paleozoic slates and argillites (Loucks 1962). The area receives approximately $1000 \mathrm{~mm}$ of precipitation annually, nearly half of which falls between June and September. The annual frost-free period is 110 days, with a mean monthly summer temperature of $15^{\circ} \mathrm{C}$.

Five blocks that had been clearcut harvested for softwood pulpwood between 1946 and 1955 were selected for the study between 1959 and 1961 (Pitt \& Lanteigne 2008). Prior to harvest, these areas were dominated by balsam fir (Abies balsamea (L.) Mill.) with minor components of red spruce (Picea rubens Sarg.) and white birch (Betula papyrifera Marsh.). At the time of site selection, they contained abundant natural regeneration of balsam fir and red spruce, with minor components of white birch and shrub species, including pin cherry (Prunus
Fig. 1 - One block (Summit Block) showing the set-up of the four treatments (unthinned control, $1.2 \mathrm{~m}, 1.8$ $\mathrm{m}$, and $2.4 \mathrm{~m}$ spacings) and position of the permanent sample plots.

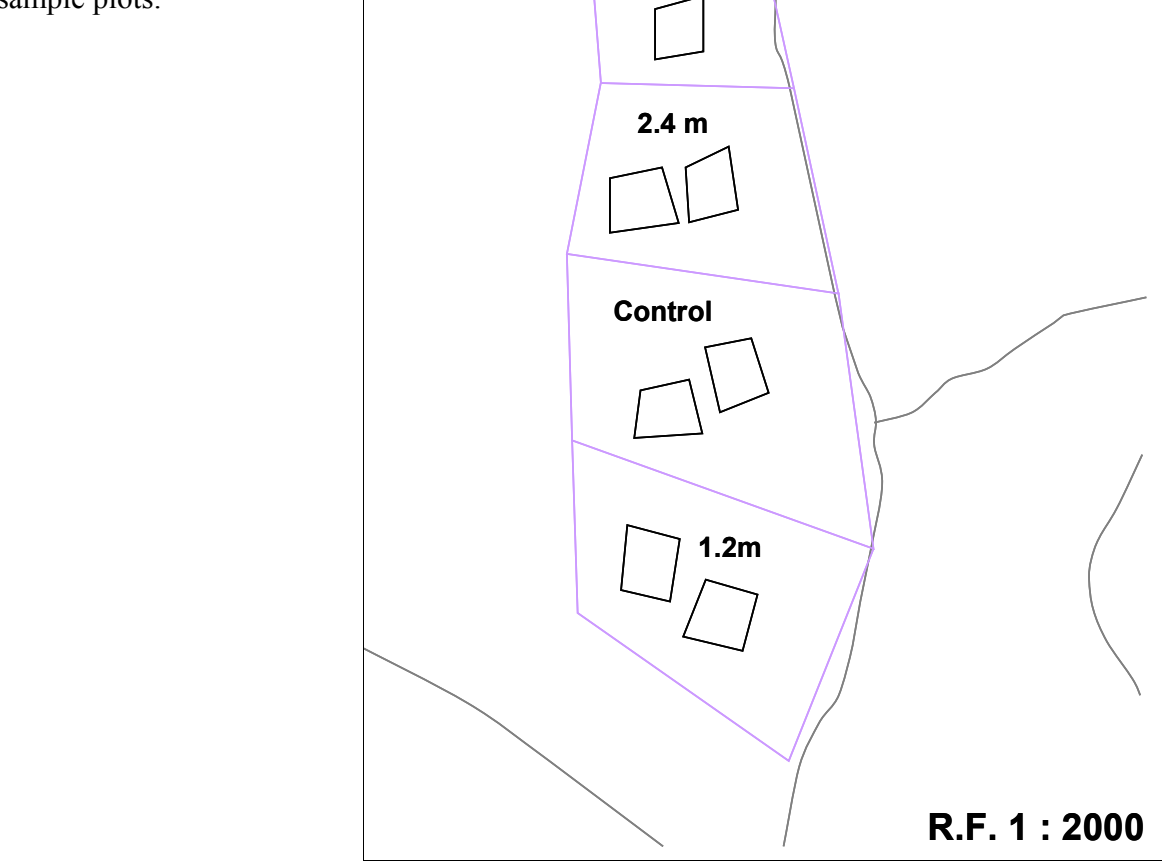

pensylvanica L.f.), mountain ash (Sorbus decora (Sarg.) C.K. Schneid.), mountain maple (Acer spicatum Lam.), elderberry (Sambucus racemosa L.), and service berry (Amelanchier spp.). Each of the five blocks was divided into four approximately equalsized treatment plots of at least 2 ha. One of the blocks (Upper Belone Bk.) was large enough ( $>16$ ha) to accommodate eight treatment plots. Within the approximate center of each half of each treatment plot, a $28.5 \mathrm{~m} \mathrm{x}$ $28.5 \mathrm{~m}(0.081 \mathrm{ha})$ permanent sample plot (PSP) was located (total of 48 PSPs - Fig. 1 ). The PSPs typically encompassed representative portions of the harvest area and extraction trails characteristic of the harvest method used. Although not specifically protected, these plots were part of large-scale spruce budworm (Christoneura fumiferana Clem.) aerial spray programs conducted throughout the region between 1953 and 1984 (Wayne MacKinnon, Canadian Forest
Service, pers. comm.).

As of 2004, treatment plots and PSPs of the Green River study were generally in good condition; plots and monumentation still intact; no excessive blowdowns present; and trees generally free of major insect, disease, and weather stresses (Pitt \& Lanteigne 2008 - Fig. 2 ). All standing trees were numbered and tagged and the PSP corners well marked. An area immediately to the north of one study block (Summit Rd. site) was harvested following the year-30 assessment and considerable blowdown ensued in the $1.8 \mathrm{~m}$ spacing treatment nearest the cut boundary. As a result of this anomaly, the data from the two PSPs in this plot were excluded from all analyses.

\section{Thinning treatments}

Three nominal spacing treatments were tested in this study: 4' $(1.2 \mathrm{~m}, 6727$ stems per ha - henceforth: sph), 6' (1.8 m, 2990

Tab. 1 - Treatment means of stand characteristics since thinning for the unthinned control and three spacing treatments.

\begin{tabular}{|c|c|c|c|c|c|c|c|c|c|c|c|c|}
\hline \multirow{2}{*}{$\begin{array}{c}\text { Years } \\
\text { Since } \\
\text { Thinning }\end{array}$} & \multicolumn{4}{|c|}{$\begin{array}{l}\text { Stems Per Ha }(x \text { 1000) } \\
\quad(>1.3 \mathrm{~m} \text { height })\end{array}$} & \multicolumn{4}{|c|}{$\begin{array}{l}\text { Dominant Height } \\
\text { (m) }\end{array}$} & \multicolumn{4}{|c|}{$\begin{array}{c}\text { Gross Total Volume } \\
\left(\mathrm{m}^{3} / \mathbf{h a}\right)\end{array}$} \\
\hline & Control & $1.2 \mathrm{~m}$ & $1.8 \mathrm{~m}$ & $2.4 \mathrm{~m}$ & Control & $1.2 \mathrm{~m}$ & $1.8 \mathrm{~m}$ & $2.4 \mathrm{~m}$ & Control & $1.2 \mathrm{~m}$ & $1.8 \mathrm{~m}$ & $2.4 \mathrm{~m}$ \\
\hline 0 & 7465 & 2415 & 1797 & 1025 & 4.6 & 5.5 & 5.9 & 5.2 & 12 & 10 & 10 & 6 \\
\hline 10 & 7989 & 3462 & 2258 & 1538 & 10.6 & 10.3 & 10.8 & 10.3 & 95 & 84 & 85 & 63 \\
\hline 20 & 5825 & 3209 & 2151 & 1549 & 13.9 & 14.1 & 14.7 & 14.2 & 181 & 185 & 185 & 155 \\
\hline 30 & 2840 & 2084 & 1631 & 1320 & 16.5 & 16.6 & 17.1 & 17.2 & 222 & 239 & 257 & 242 \\
\hline 43 & 1834 & 1626 & 1387 & 1143 & 20.3 & 20.1 & 20.7 & 20.9 & 298 & 327 & 354 & 341 \\
\hline
\end{tabular}




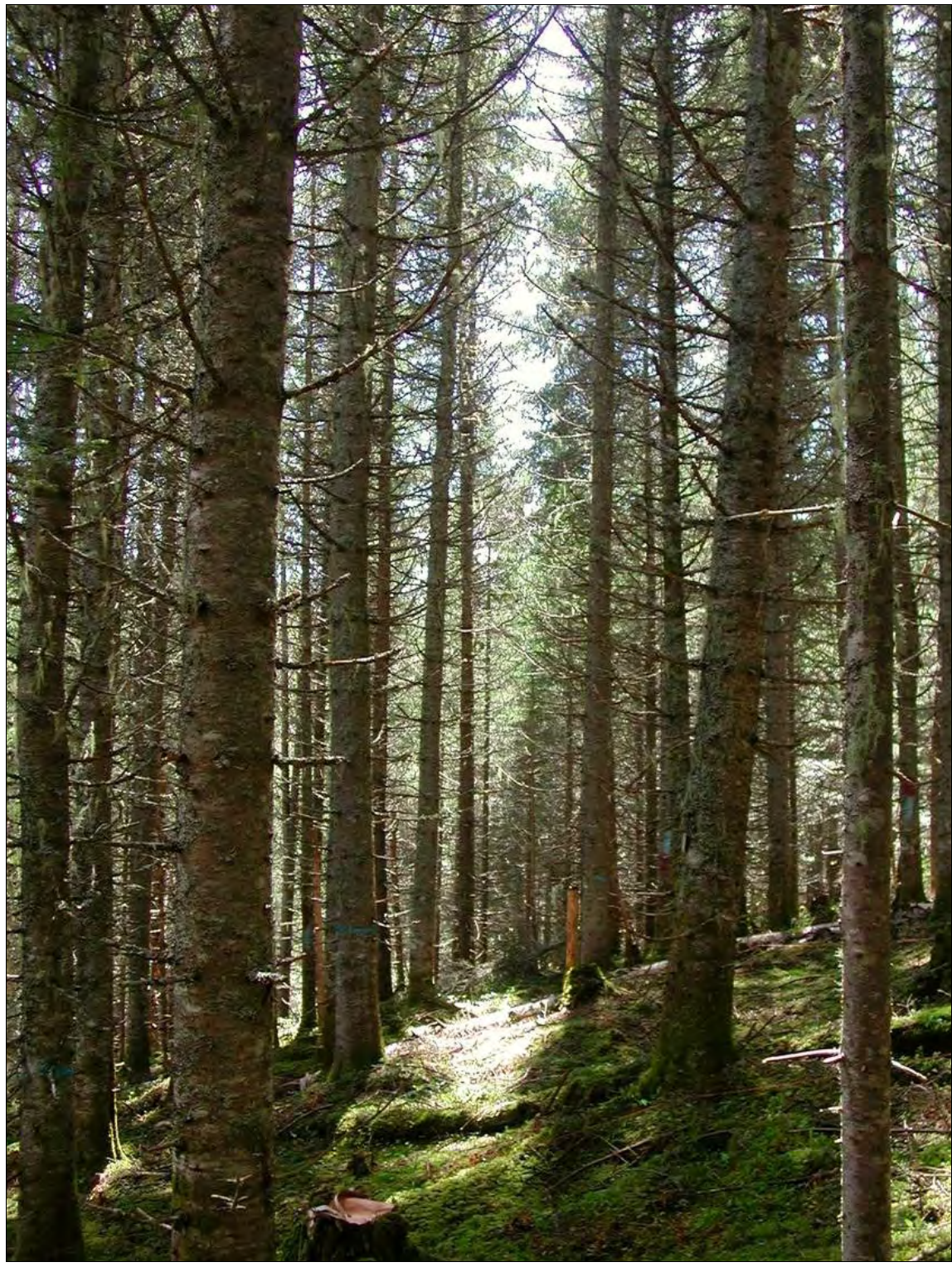

Fig. 2 - Stand condition in 2004; Lower Belone Block, 2.4 m spacing.

sph), and 8' (2.4 m, $1682 \mathrm{sph})$. Each of these three spacings and an unthinned control were assigned at random to the treatment plots in each of the five blocks. Thinning took place on the blocks late in the growing season, immediately after plot establishment (Pitt \& Lanteigne 2008). The same Fraser Paper Co. thinning crews were used each year in the study, equipped with axes and McCulloch Brushmaster circular saws. The objective of thinning was to favor uniform spacing by leaving the best spruce or fir tree at or near each spacing coordinate (Baskerville 1959). Shrubs were cleared from a $1 \mathrm{~m}$ radius around each potential crop tree. No attempts were made to compensate for the area occupied by extraction trails or natural openings within the plots. In 1972, the thinned plots were cleaned to remove trees that were, at the time of thinning, lost in the slash (Bask- erville 1965) and beginning to form a potentially competitive understory in the main stand. Tab. 1 presents summary stand characteristics of the treatments since thinning.

\section{Subplot layout and data collection}

For the purposes of our investigation, two subplots were systematically established within each PSP between July 1 and 28, 2004 , as late June to early September is the appropriate time to collect floristic data in New Brunswick (Hinds 2000). These circular (4 m radius) subplots were centered at 9 and 18 meters along a transect run diagonally through the PSP. Species-area curves leveled off in the unthinned control plots and in each of the treatment plots, indicating adequate subplot sampling among the treatments. Two field technicians completed botanical surveys in each subplot (Appendix
1). Each plant species identified was given a percent cover estimate for each layer in which it occurred (ocular estimate) following the protocols of the Forest Ecosystem Classification system (Sims et al. 1997). Layers were (i) canopy trees; (ii) sub-canopy trees; (iii) woody species $2-10 \mathrm{~m}$ height; (iv) woody species $0.5-2 \mathrm{~m}$ height; (v) woody species $<0.5 \mathrm{~m}$ height; (vi) non-woody species including herbs, grasses, sedges, ferns, and fern allies; (vii) mosses (including liverworts), and lichens. Percent cover for all layers is defined as the vertical projection onto the ground of the aerial canopy of a given species. Common species were identified in the field; others were collected as vouchers for laboratory identification.

\section{Diversity Analyses}

\section{Alpha diversity}

Diversity was measured using richness (number of species), Simpson's index, Shannon's index, Brillouin's index and Pielou's index and abundance. Simpson's index provides the probability that any two individuals selected at random from an infinitely large community are different species. Simpson's index (eqn. 1):

$$
1-\lambda=1-\sum \frac{N_{i} \cdot\left(N_{i}-1\right)}{N \cdot(N-1)}
$$

where $1-\lambda$ is Simpson's index of diversity and $N_{\mathrm{i}}$ is total proportion of the $i$-th species. This index ranges from zero, indicating low diversity, to almost 1, indicating high diversity (Krebs 1999). The Shannon-Weiner function (eqn. 2):

$$
H^{\prime}=-\sum_{i=1}^{s} P_{i} \cdot \ln P_{i}
$$

where $H^{\prime}$ is the Shannon-Weiner index of species diversity, $s$ is the total number of species, $P_{\text {i }}$ is the proportion of the total sampled belonging to the $i$-th species. The Shannon-Weiner function typically ranges from zero to five when examining biological communities, with increasing values indicating higher species diversity (Krebs 1999). The Brillouin diversity measure (eqn. 3):

$$
\hat{H}=\frac{1}{N} \cdot \log \left(\frac{N !}{n 1 ! \cdot n 2 ! \cdot n 3 ! \ldots}\right)
$$

where $H$ is Brillouin's index, $N$ is the total number of individual's in entire collection, and $n_{\mathrm{i}}$ is the total number of individual's belonging to $i$-th species (Krebs 1999).

For proportion values in both the Simpson's and Shannon-Weiner indexes, and the number of individuals in Brillouin's index, percent-cover was used in the calculations. Finally, evenness, the relative equitability of species within a community, was estimated 
using Pielou's Evenness (eqn. 4):

$$
J^{\prime}=\frac{H^{\prime}}{\log (S)}
$$

where $J^{\prime}$ is Pielou's measure of Evenness, $H^{\prime}$ is the Shannon-Wiener index of diversity and $S$ is total number of species. Pielou's measure of evenness describes the degree to which species are evenly distributed within a community (Pielou 1966). All of the estimated parameters for diversity and abundance measures were grouped into the seven layers defined above, based on 4 subplots per treatment plot and diversity indices were calculated for each layer. The treatment-plot parameter estimates for each of the seven layers were then used as raw data in analyses of variance (ANOVA) that incorporated the underlying randomized complete block experimental design (4 treatments $\mathrm{x} 5$ blocks). PROC MIXED of the SAS ${ }^{\circledR}$ System (Littell et al. 1996) was used to accommodate the additional 4 treatment plots at Upper Belone Bk. in the analysis and compute the correct least squares treatment means and standard errors. A priori contrasts were used to specifically compare the parameter estimates of a) unthinned plots (control) to the average of the wider spaced plots $(1.8 \mathrm{~m}$ and $2.4 \mathrm{~m}), \mathrm{b}$ ) control to the narrowest spaced plots $(1.2 \mathrm{~m})$, and c) the narrowest $(1.2 \mathrm{~m})$ and widest $(2.4$ m) spaced plots. In these analyses, model residuals were examined to ensure that the assumptions of homogeneity of variance and normality were met. Data transformations were not necessary.

\section{Beta Diversity}

Multivariate analyses were then used to compare community composition among the treatment and control plots. Indirect ordination (detrended correspondence analysis, DCA - ter Braak 1998) was used to identify the length of the gradients in standard deviations. Non-metric multidimensional scaling (NMS - Kruskal 1964, McCune \& Mefford 1997) was used to ordinate the plot data. In NMS, the Bray Curtis distance measure was used because of its robustness for both large and small ecological gradients (Minchin 1987). Data were standardized by species maxima, and two-dimensional solutions were appropriately chosen based on plotting a measure of fit ("stress") to the number of dimensions. One hundred iterations were used for each NMS run, using random start coordinates. The first two ordination axes were rotated to enhance interpretability (greatest spread in the clusters).

The object of discriminant function analysis is to predict multivariate responses that best discriminate the subjects in different groups (Ramsey \& Schafer 1997). Discriminant analyses were used to classify the treatment plots using the site scores from the DCA analysis, while considering any variation in the five experimental blocks. The cluster groups from the DCA site scores and the four treatments were, for each experimental unit, used as input in a discriminant analysis which 1) determined if the classification was accurate, 2) provided discriminant functions for the classification of microhabitat types and, 3 ) indicated if DCA site scores or experimental units were important variables for defining treatment clusters. This provided an independent check of the clusters identified in the DCA ordination.

\section{Results}

Diversity Analyses

\section{Alpha Diversity}

Our data indicate that the floristic diversity of PCT plots was largely restored to that of the unthinned plots four decades after treatment, or five decades after harvest. Precommercial thinning therefore appeared to have little long term effect on plant structural diversity. We observed no differences ( $p>$ 0.05 ) in the richness of any of the layers except the sub-canopy, where the thinned plots had somewhat lower richness than the unthinned ( $p=0.04$; Fig. 3 ). Similarly, orthogonal contrasts revealed no differences $(p>$ 0.05 ) related to the abundance of the seven vegetation layers, except in the case of nonwoody abundance, which was found to be lower $(p=0.04)$ in the larger spacings $(1.8 \mathrm{~m}$ and $2.4 \mathrm{~m}$ ) than in the control (Fig. 4 ). Moreover, the diversity indices measured (Simpson's diversity, Shannon's diversity, Brillouin's diversity, and Pielou's Eveness) revealed no differences $(p>0.05)$ among the treatments for any of the seven vegetation layers studied (Tab. 2 ).

\section{Beta Diversity}

Ordination analyses indicated that plant community composition and structure were similar among the PCT treatments and the unthinned control. Non-metric multidimensional scaling (NMS) and Detrended Correspondence Analysis (DCA) analyses of 96 plots and 168 species resulted in ordinations with overlapping stand groups (representing treatment plots) indicated by low eigenvalues (first axis 0.248 , gradient length 2.239
Fig. 3 - Least squares means and their standard errors for total species richness in each forest layer and the seven forest layers combined (total). Plotted values represent the averages of five blocks.

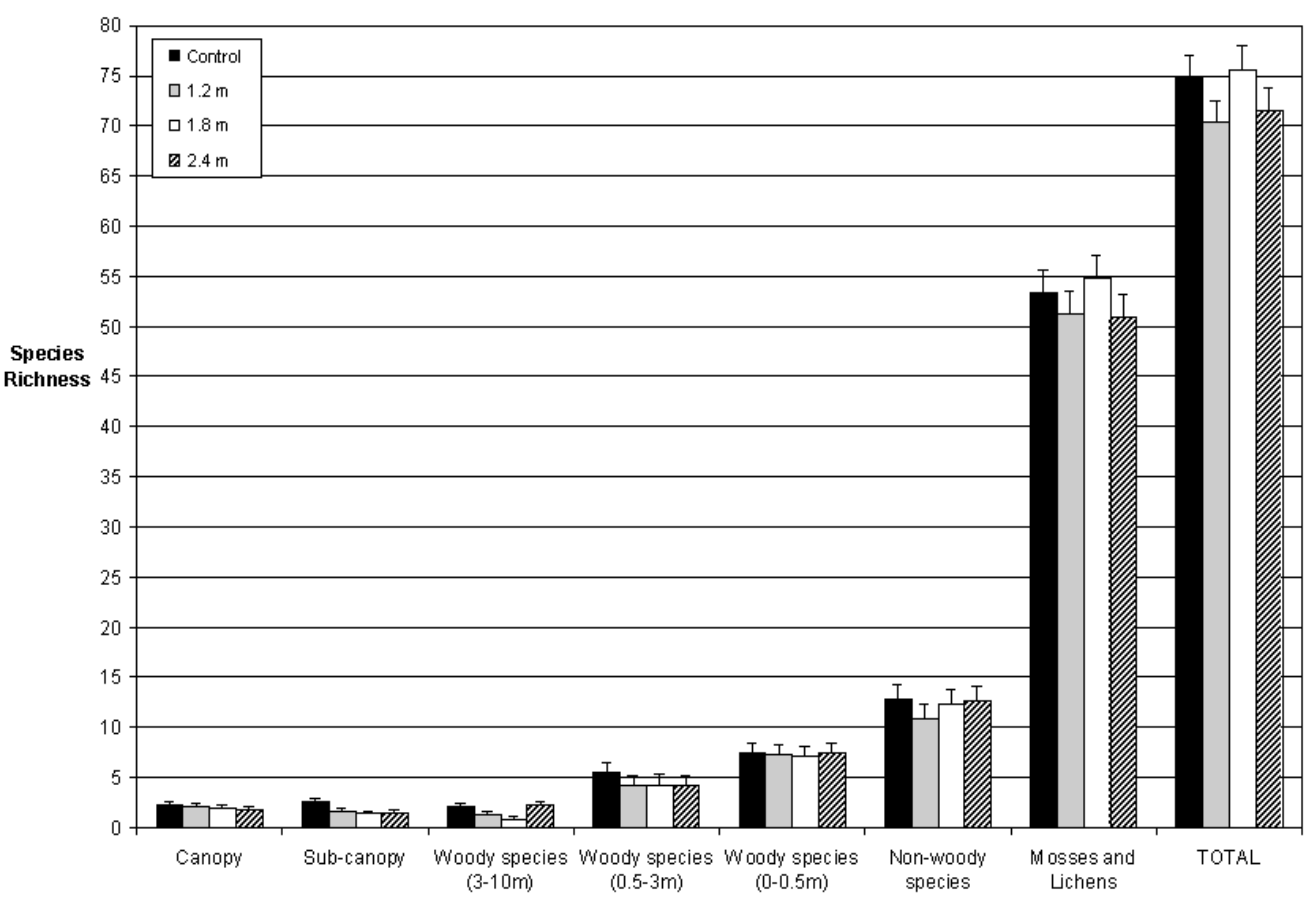




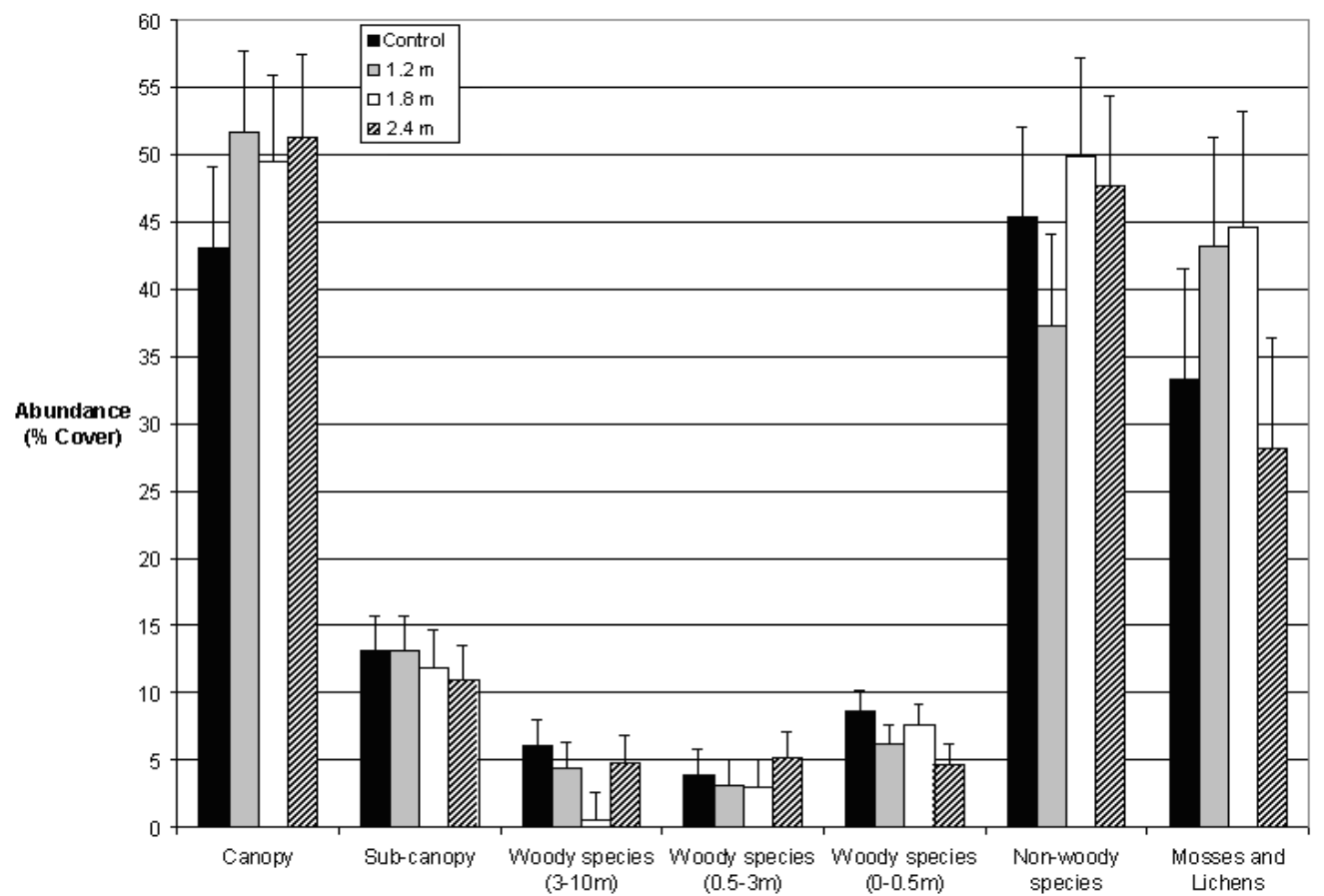

Fig. 4 - Least squares means and their standard error of total abundance (mean \% cover) of species in each forest layer. Plotted values represent the averages of five blocks.

standard deviations - Fig. 5 ). The discriminant analysis did not classify the PCT treatments based on the heterogeneity in community composition in all plants or any specific plant groups. The canonical correlation from the discriminant functions is the ratio of the between-groups sums of squares to the total sums of squares. These discriminant functions were very low $(<3 \%)$. Wilk's Lambda was used to test the hypothesis that, in the population, there are no differences between the groups (SPSS 1999). There were no differences $(p>0.05)$ for the first

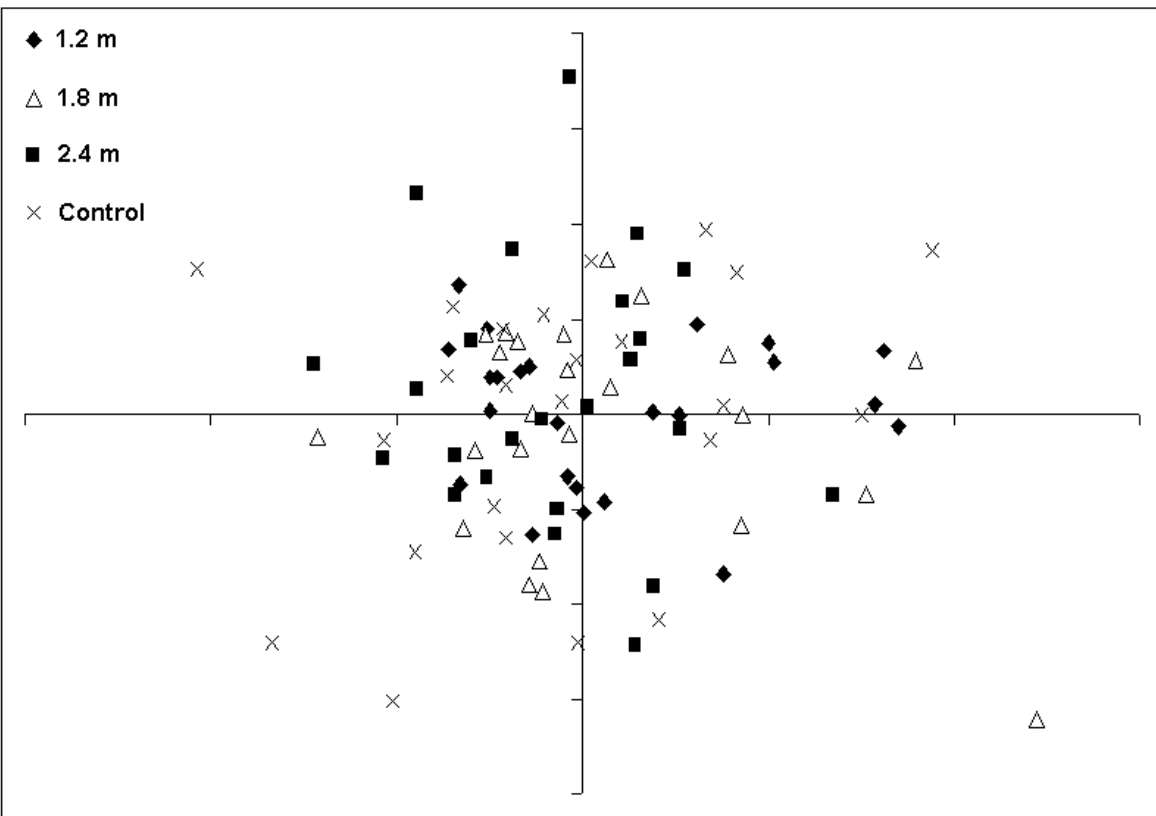

Fig. 5 - NMS ordination (stress $=0.21$ ) of 96 plots and 168 species in the control and three spacing treatments.
Tab. 2 - Least squares means (M) and their standard errors (SE) of four species diversity indices for the unthinned control and three spacing treatments.

\begin{tabular}{ccccc}
\hline Treatment & $\begin{array}{c}\text { Simpson's } \\
\text { Diversity }\end{array}$ & $\begin{array}{c}\text { Shannon's } \\
\text { Diversity }\end{array}$ & $\begin{array}{c}\text { Brillouin's } \\
\text { Diversity }\end{array}$ & $\begin{array}{c}\text { Pielou's } \\
\text { Eveness }\end{array}$ \\
\cline { 2 - 5 } & $\mathbf{M} \pm \mathbf{S E}$ & $\mathbf{M} \pm \mathbf{S E}$ & $\mathbf{M} \pm \mathbf{S E}$ & $\mathbf{M} \pm \mathbf{S E}$ \\
\hline Control & $0.7133 \pm 0.03035$ & $1.6400 \pm 0.08091$ & $1.4017 \pm 0.07724$ & $0.4233 \pm 0.02060$ \\
$1.2 \mathrm{~m}$ & $0.6983 \pm 0.03035$ & $1.5467 \pm 0.08091$ & $1.3517 \pm 0.07724$ & $0.3983 \pm 0.02060$ \\
$1.8 \mathrm{~m}$ & $0.6952 \pm 0.03160$ & $1.5452 \pm 0.08540$ & $1.3643 \pm 0.08000$ & $0.3903 \pm 0.21680$ \\
$2.4 \mathrm{~m}$ & $0.6683 \pm 0.03035$ & $1.5433 \pm 0.08091$ & $1.3200 \pm 0.07724$ & $0.3950 \pm 0.02060$ \\
\hline
\end{tabular}

two DCA axes scores attributed to the experimental units (blocks).

\section{Discussion}

Some researchers predict that thinning of the forest overstory may result in increased light penetration into the understory, which will favor the development of forest floor vegetation (Bailey et al. 1998, Thomas et al. 1999, He \& Barclay 2000, Lindgren et al. 2006). However, there appears to be a paradox in the results of several thinning research trials that suggest the dynamic nature of forest plant communities may override the influence of a particular limiting resource such as light.

The results are contradictory, ranging from no differences (Moola \& Vasseur 2004, Kern et al. 2006, He \& Barclay 2000, Berger \& Puettmann 2000, Thomas et al. 2001), to diversity going significantly higher (Lindgren et al. 2006, Decocq et al. 2004, Bailey et al. 1998, Thysell \& Carey 2000, Battles et al. 2001), or lower (Thomas et al. 1999, Jobidon et al. 2004, Hansen et al. 1991, Elliott et al. 1997) following canopy thinning. Jobidon et al. (2004) investigated the influence of thin- 
ning and found that large increases in hardwood productivity occurred at the expense of species richness and diversity of the understory stratum, which could not be explained by variability in canopy light. Much of the discrepancies in these research results can be attributed to different thinning intensities, time since thinning, or the type of forest ecosystem.

Thinning intensity imposes different effects on plant diversity. Below a certain level of thinning intensity, species richness increases with the intensity of thinning (Newmaster et al. 2006, Decocq et al. 2004). Moderate thinning (e.g., up to two thirds of basal area removed) is expected to promote understory species diversity, which was found to decrease under the heavy thinning performed in many types of forest (Alaback \& Herman 1988, Reader et al. 1991).

Studies in which thinning treatments appear to have had an effect on understory vegetation have largely involved early successional forests (2-20 years post thinning). Otsamo (2002) found dramatic changes in understory vegetation in a spacing trial, which he attributed to differences in light intensity under different canopies, including a canopy species $\times$ spacing interaction. Researchers need to consider the importance of time since thinning and the consequences of natural recovery of plant diversity.

Long-term thinning studies indicate recovery of understory vegetation. There are relatively few long term thinning trials $(>27$ years) and surprisingly all of these studies report the recovery of understory vegetation. He \& Barclay (2000) found that, after 27 years thinning and fertilization in conifer stands had little effect on understory vegetation richness or vegetation cover. Other studies have recorded the effects at longer times since thinning, suggesting that recovery of understory species requires at least 50 years according to Metzger \& Schultz (1984) and at least 80 years according to Duffy \& Meier (1992). Kern et al. (2006) reported that ground-layer plant communities in northern ecosystems are either resistant to change, or have recovered within the 40 years since disturbance in the even-age treatments, and within 10 years since disturbance in the uneven-age treatments. Unfortunately, none of these studies have recorded vegetation in regular intervals beyond 20 years; they only provide a single long term (usually $>40$ years) assessment of recovery.

\section{Explanation for effects observed at Green River}

The Green River LTR provides an example of understory regeneration within forty years post-precommercial thinning. Our results are supported by other LTR thinning trials in both conifer and hardwood stands (Metzger \& Schultz 1984, Kern et al. 2006, He \&
Barclay 2000). We sampled at a single point in time 4 decades after thinning and found no differences in the floristic diversity between our unthinned controls and nominal thinning spacings between 1.2 and $2.4 \mathrm{~m}$. However, we cannot discount the possibility of earlier $(<20$ years $)$ differences among these treatments, which could be consistent with the findings at other thinning trials (Gilliam et al. 1995, Halpern \& Spies 1995). Full crown closure and subsequent intraspecific competition took place on the Green River plots about 15 years after PCT (Pitt \& Lanteigne 2008). We suspect that any differences that existed between thinned and unthinned understories would have attenuated subsequent to this point in time.

Authors of most of the thinning research trials have commented on the dynamic nature of forest plant communities (Alaback \& Herman 1988, He \& Barclay 2000). A detailed look at the species reveal that some forest generalist species appear to tolerate treatments such as canopy spacing through the allocation of resources to growth, reproduction, or survival (Eriksson 1993, Damman \& Cain 1998). Other forest species are absent because of the lack of forest structure including microhabitats (Boudreault et al. 2002, Bell \& Newmaster 2002). One might expect that major changes in understory vegetation occur between $10-30$ years. McWilliams \& Thérien (1996) reported that differences between thinning treatments and controls were narrowing considerably over time (27-year study). It is crucial that the short term research trials continue to gather data in order to determine if the understory vegetation recovers and if so at what temporal threshold following PCT.

Alternatively, the intensity of canopy thinning at the Green River trial may have been too low to influence understory vegetation. As stated earlier, thinning intensity imposes different effects on plant diversity (Newmaster et al. 2006, Decocq et al. 2004, Alaback \& Herman 1988, Reader et al. 1991). In a mature forest there is often no difference in understory communities between small gaps $\left(33 \mathrm{~m}^{2}\right)$ and closed canopy; higher understory richness is associated with mid (60-85 $\mathrm{m}^{2}$ ) to large $\left(120-190 \mathrm{~m}^{2}\right.$ ) gaps (Anderson \& Leopold 2002). He \& Barclay (2000) suggested that the marginal differences in canopy opening from thinning treatments were not big enough to have discernible effects on the majority of understory species. In another study of restoration in conifer plantations, Newmaster et al. (2006) found that wider spacings ( $2.7 \mathrm{~m}$ and $3.6 \mathrm{~m}$ ) resulted in higher richness, lower woody plant abundance, slightly higher cover of herbaceous plants, and large increases in cryptogam cover. The Green River trial spacing was narrower (1.2 $\mathrm{m}, 1.8 \mathrm{~m}, 2.4 \mathrm{~m}$ ) and, as such, we cannot discount the possibility that these narrow tree spacings do not change the light resources sufficiently to affect plant community structure and diversity - at least over the longerterm.

\section{Forest Diversity}

Silvicultural systems could adopt restoration goals that aim to recover or sustain native and late-successional species diversity, while also meeting goals for timber production. Contemporary silvicultural systems have been moving in this direction for a wide variety of forest ecosystems (e.g., Muir et al. 2002, Seymour et al. 2002, Palik \& Zasada 2003, Aubry et al. 2004, Kern et al. 2006). Goals need to sustain the plant species that coexist in different forest ecosystems along site quality gradients (Roberts \& Gilliam 1995, Lindenmayer et al. 2000, Aubert et al. 2003). For example, Jobidon et al. (2004) has suggested a strategy aiming to maximise productivity by means of precommercial thinning treatments that will maintain or even increase stand structural diversity, which helps protect biodiversity, without affecting understory plant species diversity.

Precommercial thinning is a variable silvicultural tool that could be used to attain both economic productivity and biodiversity restoration goals. In general, thinning stands leads to positive responses in biomass (Thomas et al. 1999, Sullivan et al. 2001), with the added benefits of control over forest species composition. For example, in eastern Canada, PCT treatments are used to maintain a proportion of deciduous tree species within canopy of spruce spacing trials (MNRQ 1994, Jobidon et al. 2004). Conventional PCT prescribes a single target density to an entire stand. Forest managers could, however, implement restoration goals that compensate for the strong early successional response of understory vegetation to thinning by varying the intensity of thinning within and among stands, leaving a mixture of open and dense canopies. Although we have shown that after forty years, plant diversity was comparable between thinned and unthinned stands, in other forest ecosystems, the limited dispersal and slow rate of growth of some native species may prevent their recovery (Bierzychudek 1982, Roberts \& Zhu 2002). Further research is needed to investigate the habitat and dispersal requirements of native species with respect to the size of fragmented forest (Radtke \& Burkhart 1998, Newmaster et al. 2006). Further research on understory diversity consequences of very high thinning intensities is needed, and would be of direct relevance to "new forestry" methods such as green tree retention (Tappeiner et al. 1997, Halpern et al. 1999, Thomas et al. 1999). We recommend a shift away from focusing on the effects of forest management on biodiversity, and in- 
stead to try to better understand the underlying mechanisms in ecology that will serve forest managers and conservationists as tools in the preservation of biodiversity.

\section{Acknowledgements}

We are greatly indebted to Dr. Gordon Baskerville for his foresight and early efforts in the sound establishment of the Green River thinning trials. The long and continued efforts of a number of field and office personnel over the years have kept this study "alive". At the risk of missing some of these folks, they include B.J. Akerly, Rodney Foster, Mike Ker, Mike Lavigne, Wayne Malloy, Gerrit van Raalte, and Ben Weale. To the credit of Nexfor Fraser Papers Inc., now Acadian Timber, (Kevin Topolniski, Luc Ouellette, and Gordon Whitmore) and N.B. Department of Natural Resources and Energy, these plots have been carefully protected through the years and remain relatively undisturbed. We would also like to thank Tara Stephens, Chris Roosenboom, and Trevor Wilson for their assistance in the field and at the herbarium. Aron Fazekas and Candice Newmaster provided editorial support for which we a grateful. Funding for the 2004 measurements and analysis was provided by the Canadian Forest Service, Canadian Ecology Centre - Forestry Research Partnership, and the New Brunswick Growth and Yield Committee.

\section{References}

Akerley BJ (1961). Establishment report - Cleaning and thinning young fir, 1961 Project M-44359. Internal report, Department of Northern Affairs and National Resources, Forestry Branch, Maritimes District, Fredericton, New Brunswick, pp. 29.

Alaback PB, Herman FR (1988). Long-term response of understorey vegetation to stand density in Picea-Tsuga forests. Canadian Journal of Forest Research 18: 1522-1530. - doi: 10.1139/x 88-233

Anderson KL, Leopold DJ (2002). The role of canopy gaps in maintaining vascular plant diversity at a forested wetland in New York state. Journal of the Torrey Botanical Society 129: 238-250. - doi: 10.2307/3088774

Aubert M, Alard D, Bureau, F (2003). Diversity of plant assemblages in managed temperate forests: a case study in Normandy (France). Forest Ecology and Management 175: 321-337. - doi: 10.1016/S0378-1127(02)00215-3

Aubry KB, Halpern CB, Maguire DA (2004). Ecological effects of variable-retention harvests in the northwestern United States: the DEMO study. Forest Snow and Landscape Research 78: 119-137.

Bailey JD, Mayrsohn C, Deoscher PS, St. Pierre E, Tappeiner JC (1998). Understory vegetation in old and young Douglas-fir forests of western Oregon. Forest Ecology and Management 112: 289-302. - doi: 10.1016/S0378-1127(98)00408-3
Baskerville GL (1959). Establishment reportCleaning and thinning young fir, 1960 Project M-443-59. Internal report, Department of Northern Affairs and National Resources, Forestry Branch, Maritimes District, Fredericton, New Brunswick, pp. 28.

Baskerville GL (1961). Establishment report Cleaning and thinning young fir, 1960 Project M-443-59. Internal report, Department of Northern Affairs and National Resources, Forestry Branch, Maritimes District, Fredericton, New Brunswick, pp. 5.

Baskerville GL (1965). Progress report - Cleaning and thinning young fir, 1959 - Project M-443-59. Internal report, Department Forestry, Maritimes District, Fredericton, New Brunswick, pp. 18.

Baskerville GL, Hughes EL, Loucks OL (1960). Research by the Federal Forestry Branch in the Green River Project. The Forestry Chronicle 36: 265-277.

Battles JJ, Shlisky AJ, Barrett RH, Heald RD, Allen-Diaz BH (2001). The effects of forest management on plant species diversity in a Sierran conifer forest. Forest Ecology and Management 146: 211-222. - doi: 10.1016/S03781127(00)00463-1

Bell FW, Newmaster SG (2002). The effects of silvicultural disturbances on the diversity of seed producing plants in the boreal mixedwood forest. Canadian Journal of Forest Research 32: 11801191. - doi: 10.1139/x02-024

Berger AL, Puettmann KJ (2000). Overstory composition and stand structure influence herbaceous plant diversity in the mixed aspen forest of northern Minnesota. American Midland Naturalist 143: 111-125. - doi: 10.1674/00030031(2000)143[0111:OCASSI]2.0.CO;2

Bierzychudek P (1982). Life histories and demography of shade-tolerant temperate forest herbs: a review. New Phytologist 90: 757-776. - doi: 10.1111/j.1469-8137.1982.tb03285.x

Boudreault C, Bergeron Y, Gauthier S, Drapeau P (2002). Bryophyte and lichen communities in mature to old-growth stands in eastern boreal forests of Canada. Canadian Journal of Forest Research 32:1080-1093. - doi: 10.1139/x02-027

CCFM (2005). Canadian Council of Forest Ministers; National Forestry Database Program, Compendium of Canadian Forestry Statistics. [online] URL: http://nfdp.ccfm.org

Curtis RO, Carey AB (1996). Timber supply in the Pacific northwest: managing for economic and ecological values in Douglas-fir forest. Journal of Forestry 94: 4-7, 35-37.

Curtis RO, Marshall DD, Bell JF (1997). LOGS: a pioneering example of silvicultural research in coast Douglas-fir. Journal of Forestry 95: 19-25.

Damman H, Cain M (1998). Population growth and viability analysis of the clonal woodland herb Asarum canadense. Journal of Ecology 86: 13-26. - doi: 10.1046/j.1365-2745.1998.00242.x

Decocq G, Aubert M, Dupont F, Alard D, Saguez R, Wattez-Franger A, de Foucault B, DelelisDusollier A, Bardat J (2004). Plant diversity in a managed temperate deciduous forest: understorey response to two silvicultural systems.
Journal of Applied Ecology 41: 1065-1079. - doi: 10.1111/j.0021-8901.2004.00960.x

Duffy DC, Meier AJ (1992). Do Appalachian herbaceous understories ever recover from clearcutting? Conservation Biology 6: 196-201. - doi: 10.1046/j.1523-1739.1992.620196.x

Elliott KJ, Boring, LR, Swank WT, Haines BR (1997). Successional changes in plant species diversity and composition after clearcutting a southern Appalachian watershed. Forest Ecology and Management 92: 67-85. - doi: 10.1016/S0378-1127(96)03947-3

Eriksson O (1993). Dynamics of genets in clonal plants. Trends in Ecology \& Evolution 8: 313316. - doi: 10.1016/0169-5347(93)90237-J

Gilliam FS, Roberts MR (1995). Impacts of forest management on plant diversity. Ecological Applications 5:911-912. - doi: 10.2307/2269342

Gilliam FS, Turrill NL, Adams MB (1995). Hebaceous-layer and overstory species in a clearcut and mature central Appalachian hardwood forests. Ecological Applications 5: 947-955. doi: $10.2307 / 2269345$

Halpern CB, Evans SA, Nelson CR, McKenzie D, Liguori DA, Hibbs DE, Halaj MG (1999). Responses of forest vegetation to varying levels and patterns of green-tree retention: an overview of a long-term experiment. Northwest Science 73: 27 44.

Halpern CB, Spies TA (1995). Plant species diversity in natural and managed forest of the $\mathrm{Pa}$ cific northwest. Ecological Applications 5: 913934. - doi: 10.2307/2269343

Hansen AJ, Spies TA, Swanson FJ, Ohmann JL (1991). Conserving biodiversity in managed forests, lessons from natural forests. BioScience 41: 382-392. - doi: 10.2307/1311745

He F, Barclay HJ (2000). Long-term response of understory plant species to thinning and fertilization in a Douglas-fir plantation on southern Vancouver Island, British Columbia. Canadian Journal of Forest Research 30: 566-572. - doi: $10.1139 /$ jjfr-30-4-566

Hinds HR (2000). Flora of New Brunswick ( $2^{\text {nd }}$ edn). University of New Brunswick Press, Fredericton, New Brunswick, pp. 695.

Jobidon R, Cyr G, Thiffault N (2004). Plant species diversity and composition along an experimental gradient of northern hardwood abundance in Picea mariana plantations. Forest Ecology and Management 198: 209-221. - doi: 10.1016/j.foreco.2004.04.020

Ker MF (1981). Early response of balsam fir to spacing in northwestern New Brunswick, Maritimes Forest Research Centre, Maritime Forest Research Center Information Report M-X-129, pp. 36.

Ker MF (1987). Effects of spacing on balsam fir: 25-year results from the Green River spacing trials. In: Proceedings of the precommerical thinning workshop, March 19, 1987, Hugh John Fleming Forestry Complex. Canada/New Brunswick Forest Renewal Agreement Publication (Murray TS, Cameron MD eds). Canadian Forest Service- Maritimes, P.O. Box 4000, Fredericton, New Brunswick, pp. 59-75. 
Kern CC, Palik BJ, Stron TF (2006). Ground-layer plant community responses to even-age and uneven-age silvicultural treatments in Wisconsin northern hardwood forests. Forest Ecology and Management 230: 162-170. - doi: 10.1016/j.foreco.2006.03.034

Krebs CJ (1999). Ecological Methodology (2 $2^{\text {nd }}$ edn). Addison Wesley Longman, Inc. Don Mills, Ontario.

Kremsater LL, Bunnell FL (1998). Changing forests, shifting values, and chronosequence research. Northwest Science 72: 9-17.

Kruskal JB (1964). Non-metric multidimensional scaling: a numerical method. Psychometrika 29: 115-129. - doi: 10.1007/BF02289694

Larsson S, Danell K (2001). Science and the management of boreal forest biodiversity. Scandinavian Journal of Forest Research Supplement 3:5-9. - doi: 10.1080/028275801300090528

Lindenmayer DB, Margules CR, Botkin DB (2000). Indicators of biodiversity for ecologically sustainable forest management. Conservation Biology 14: 941-950. - doi: 10.1046/j.15231739.2000.98533.x

Lindgren PMF, Ransome DB, Sullivan DS, Sullivan TP (2006). Plant community attributes 12 to 14 years following precommercial thinning in a young lodgepole pine forest. Canadian Journal of Forest Research 36: 48-61. - doi: 10.1139/x05228

Littell RC, Milliken GA, Stroup WW, Wolfinger RD (1996). SAS $^{\circledR}$ System for Mixed Models. SAS Institute Inc., Cary, NC, pp. 633.

Loucks OL (1962). A forest classification for the Maritime Provinces. Proceedings of the Nova Scotian Institute of Science 25: 86-167.

MNRQ (1994). Ministère des Ressources naturelles du Québec. Une stratégie- Aménages pour miew protéger le forêts. Direction des programmes forestiers, Québec.

McCune B, Mefford MJ (1997). PC-ORD. Multivariate analysis of ecological data (version 3.20). MjM Software Design, Gleneden Beach, OR, USA.

McWilliams ERG, Thérien G (1996). Fertilization and thinning effects on a Douglas-fir ecosystem at Shawnigan Lake: 24-year growth response. British Columbia Ministry of Forests; Forest Research Development Agreement Report 269, ISSN: 0835-0752.

Metzger F, Schultz J (1984). Understory response to 50 years of management of a northern hardwood forest in upper Michigan. American Midland Naturalist 112: 209-223. - doi: 10.2307/2425428

Minchin PR (1987). An evaluation of the relative robustness of techniques for ecological ordination. Vegetatio 69: 89-107. - doi: 10.1007/BF00038690

Moola FM, Vasseur L (2004). Recovery of lateseral vascular plants in a chronosequence of postclearcut forest stands in coast Nova Scotia, Canada. Plant Ecology 172: 183-197. - doi:
10.1023/B:VEGE.0000026326.09137.06

Muir PS, Mattingly RL, Tappeiner JC, Bailey JD, Elliot WE, Hagar JC, Miller JC, Peterson, EB, Starkey EE (2002). Managing for biodiversity in young Douglas-fir forests of western Oregon. USGS, Biol. Res. Div., Biol. Sci. Rep. 76.

Newmaster SG, Bell FW, Roosenboom, CR, Cole HA, Towill WD (2006). Restoration of floral diversity through plantations on abandoned agricultural land. Canadian Journal of Forest Research 36: 1218-1235. - doi: 10.1139/X06-021

Okland T, Rydgren K, Okland RH, Storaunet KO, Rolstad J (2003). Variation in environmental conditions, understorey species number, abundance and composition among natural and managed Picea abies forest stands. Forest Ecology and Management 177: 17-37. - doi: 10.1016/S0378-1127(02)00331-6

Otsamo A (2002). Early effects of four fast-growing tree species and their planting density on ground vegetation in Imperata grasslands. New Forests 23: 1-17. - doi: 10.1023/A:1015655923484

Palik BJ, Zasada JC (2003). An ecological context for regenerating multi-cohort, mixed-species red pine forests. USDA Forest Service, North Central Research Station, Research Note NC-382.

Pielou EC (1966). The measurement of diversity in different types of biological collections. Journal of Theoretical Biology 13: 131-1. - doi: 10.1016/0022-5193(66)90013-0

Pitt DG, Lanteigne L (2008). Long-term outcome of precommercial thinning in northwestern New Brunswick: growth and yield of balsam fir and red spruce. Canadian Journal of Forest Research 38: 592-610. - doi: 10.1139/X07-132

Radtke J, Burkhart E (1998). A comparison of methods for edge-bias compensation. Canadian Journal of Forest Research 28: 942-945. - doi: 10.1139/cjfr-28-6-942

Ramovs BV, Roberts MR (2003). Understory vegetation and environment responses to tillage, forest harvesting, and conifer plantation development. Ecological Applications 13: 1682-1700. doi: 10.1890/02-5237

Ramsey FL, Schafer DW (1997). The statistical sleuth: a course in methods of data analysis. Duxbury Press, Belmont, CA (USA).

Reader RJ, Taylor KC, Larson DW (1991). Does intermediate disturbance increase species richness within deciduous forest understory? In: "Modern ecology: basic and applied aspects" (Esser G, Overdieck D eds). Elsevier, Amsterdam, pp. 363-374.

Roberts MR, Gilliam FS (1995). Patterns and mechanisms of plant diversity in forested ecosystems: implications for forest management. Ecological Applications 5: 969-977. - doi: 10.2307/2269348

Roberts MR, Zhu L (2002). Early response of the herbaceous layer to harvesting in a mixed coniferous-deciduous forest in New Brunswick, Canada. Forest Ecology and Management 155:
17-31. - doi: 10.1016/S0378-1127(01)00544-8

Rowe JS (1972). Forest regions of Canada. Department of the Environment, Canadian Forestry Service, Publication No. 1300, Ottawa, pp. 172. SPSS (1999). Professional base system software for statistical analysis. SPSS Inc. Chicago (USA).

Seymour RS, White AS, deMaynadier PD (2002). Natural disturbance regimes in northeastern North America - evaluating silvicultural systems using natural scales and frequencies. Forest Ecology and Management 155: 357-367. - doi: 10.1016/S0378-1127(01)00572-2

Sims RA, Towill WD, Baldwin KA, Uhlig P, Wickware GM (1997). Field guide to the forest ecosystem classification for northwestern Ontario. Ontario Ministry of Natural Resources, Northwest Science and Technology, Thunder Bay, Ontario Field Guide FG-03.

Smith DM (1986). The practice of silviculture $\left(8^{\text {th }}\right.$ edn). John Wiley \& Sons Inc., NY, pp. 572.

Spence JR (2001). The new boreal forestry: adjusting timber management to accommodate biodiversity. Trends in Ecology \& Evolution 16: 591-593. - doi: 10.1016/S0169-5347(01)02335-7 Sullivan TP, Sullivan DS, Lindgren PMF (2001). Stand structure and small mammals in young lodgepole pine forest: 10-year results after thinning. Ecological Applications 11: 1151-1173. doi: 10.1890/1051-0761(2001)011[1151:SSASMI]2.0.CO;2

Tappeiner JC, Lavender D, Walstad J, Curtis RO, DeBell DS (1997). Silvicultural systems and regeneration methods: current practices and new alternatives. In: "Creating a forestry for the $21 \mathrm{st}$ century" (Kohm K, Franklin JF eds). Island Press, Washington, DC (USA), pp. 151-165.

Thomas SC, Halpern CB, Falk DA, Liguori DA, Austin KA (1999). Plant diversity in managed forests: understory responses to thinning and fertilization. Ecological Applications 9: 864-879. doi: 10.1890/1051-0761(1999)009[0864:PDIMFU]2.0.CO;2

Thomas SC, Liguori DA, Halpern CB (2001). Corticolous bryophytes in manages Douglas-fir forests: habitat differentiation and responses to thinning and fertilization. Canadian Journal of Botany 79: 886-896. - doi: 10.1139/cjb-79-8-886 Thysell DR, Carey AB (2000). Effects of forest management on understory and overstory vegetation: a retrospective study. US Forest Service $\mathrm{Pa}$ cific Northwest Research Station General Technical Report PNW-GTR-488.

Vallauri DR, Aronson J, Barbero M (2002). An analysis of forest restoration 120 years after reforestation on badlands in the southwestern Alps. Restoration Ecology 10: 16-26. - doi: 10.1046/j.1526-100X.2002.10102.x

ter Braak CJF (1998). CANOCO reference manual and user's guide to CANOCO for Windows. Center for Biometry, Wageningen, The Netherlands. 


\section{Appendix 1}

Abundance ( $\%$ cover by ocular estimate) and frequency $(\%)$ of species occurrence in sublots (total $=24)$ for unthinned control and three spacing treatments.

\begin{tabular}{|c|c|c|c|c|c|c|c|c|c|c|c|c|c|c|c|c|c|c|c|}
\hline \multirow{3}{*}{ Layer } & \multirow{3}{*}{ Species } & \multicolumn{8}{|c|}{ Treatments } & \multirow{3}{*}{ Layer } & \multirow{3}{*}{ Species } & \multicolumn{8}{|c|}{ Treatments } \\
\hline & & \multicolumn{2}{|c|}{ Control } & \multicolumn{2}{|c|}{$1.2 \mathrm{~m}$} & \multicolumn{2}{|c|}{$1.8 \mathrm{~m}$} & \multicolumn{2}{|c|}{$2.4 \mathrm{~m}$} & & & \multicolumn{2}{|c|}{ Control } & \multicolumn{2}{|c|}{$1.2 \mathrm{~m}$} & \multicolumn{2}{|c|}{$1.8 \mathrm{~m}$} & \multicolumn{2}{|c|}{$2.4 \mathrm{~m}$} \\
\hline & & Abun. & Freq. & Abun. & Freq. & Abun. & Freq. & Abun. & Freq. & & & Abun. & Freq. & Abun. & Freq. & Abun. & Freq. & Abun. & Freq. \\
\hline \multirow[t]{5}{*}{ Canopy } & Abies balsamea & 36 & 100 & 47 & 100 & 46 & 100 & 48 & 100 & \multirow{7}{*}{$\begin{array}{l}\text { Woody Species } \\
(0.5-2 \mathrm{~m}) \\
\text { (cont.) }\end{array}$} & Prunus pensylvanica & 0.4 & 13 & 0 & 0 & 0 & 0 & 0.1 & 4 \\
\hline & Acer saccharum & 0 & 0 & 0.1 & 4 & 0 & 0 & 0 & 0 & & Ribes lacustre & 0 & 0 & 0 & 0 & 0.1 & 4 & 0.1 & 4 \\
\hline & Betula alleghaniensis & 10 & 4 & 0 & 0 & 0 & 0 & 0 & 0 & & Rubus idaeus & 0 & 0 & 0 & 0 & 1 & 4 & 0 & 0 \\
\hline & Betula papyrifera & 10 & 8 & 20 & 4 & 0 & 0 & 0 & 0 & & ssp.idaeus & & & & & & & & \\
\hline & Picea rubens & 8 & 71 & 8 & 46 & 7 & 58 & 8 & 42 & & $\begin{array}{l}\text { Sambucus racemosa } \\
\text { var.racemosa }\end{array}$ & 0 & 0 & 0 & 0 & 0.1 & 8 & 0 & 0 \\
\hline \multirow[t]{5}{*}{ Sub-Canopy } & Abies balsamea & 10 & 88 & 14 & 88 & 13 & 75 & 10 & 96 & & Sorbus decora & 0.1 & 29 & 0.1 & 21 & 0.1 & 13 & 0.1 & 8 \\
\hline & Betula alleghaniensis & 5 & 4 & 0 & 0 & 0 & 0 & 0 & 0 & & Viburnum lantanoides & 0.1 & 4 & 0 & 0 & 0 & 0 & 0.1 & 4 \\
\hline & Betula papyrifera & 7 & 38 & 0.1 & 4 & 10 & 4 & 3 & 8 & \multirow{23}{*}{$\begin{array}{l}\text { Woody Species } \\
(<0.5 \mathrm{~m})\end{array}$} & Abies balsamea & 8 & 100 & 5 & 100 & 7 & 100 & 4 & 100 \\
\hline & Picea rubens & 8 & 17 & 2 & 21 & 1 & 21 & 8 & 17 & & Acer pensylvanicum & 0.1 & 4 & 0.1 & 13 & 0.1 & 8 & 0.1 & 17 \\
\hline & Sorbus decora & 5 & 4 & 0 & 0 & 0 & 0 & 0 & 0 & & Acer rubrum & 0.1 & 4 & 0.1 & 17 & 0.1 & 13 & 0.1 & 21 \\
\hline \multirow{7}{*}{$\begin{array}{l}\text { Woody Species } \\
(2-10 \mathrm{~m})\end{array}$} & Abies balsamea & 6 & 63 & 8 & 50 & 2 & 38 & 18 & 25 & & Acer saccharum & 0 & 0 & 0 & 0 & 0.3 & 17 & 0.1 & 4 \\
\hline & Acer saccharum & 0 & 0 & 0 & 0 & 0.1 & 4 & 1 & 4 & & Acer spicatum & 0.1 & 25 & 0.1 & 33 & 0.2 & 33 & 0.1 & 33 \\
\hline & Acer spicatum & 1 & 4 & 0 & 0 & 0 & 0 & 0 & 0 & & Amelanchier laevis & 0 & 0 & 0 & 0 & 0.1 & 4 & 0 & 0 \\
\hline & Amelanchier spp. & 0 & 0 & 0 & 0 & 0 & 0 & 0.1 & 4 & & Amelanchier spp. & 0.1 & 8 & 0.1 & 4 & 0.1 & 8 & 0.1 & 4 \\
\hline & Betula alleghaniensis & 0 & 0 & 0 & 0 & 0 & 0 & 0.1 & 4 & & Betula alleghaniensis & 0.2 & 54 & 0.2 & 54 & 0.3 & 42 & 0.2 & 58 \\
\hline & Betula papyrifera & 4 & 54 & 0 & 0 & 0 & 0 & 0.7 & 13 & & Betula papyrifera & 0.2 & 83 & 0.2 & 75 & 0.2 & 75 & 0.1 & 67 \\
\hline & Picea rubens & 0 & 0 & 3 & 8 & 0 & 0 & 0.7 & 13 & & Corylus cornuta & 0 & 0 & 0.1 & 4 & 0 & 0 & 0.1 & 4 \\
\hline \multirow{13}{*}{$\begin{array}{l}\text { Woody Species } \\
(0.5-2 \mathrm{~m})\end{array}$} & Abies balsamea & 3 & 58 & 4 & 42 & 0 & 0 & 0.1 & 4 & & ssp.cornuta & & & & & & & & \\
\hline & Acer pensylvanicum & 1 & 4 & 0.1 & 8 & 0 & 0 & 0.1 & 4 & & Linnaea borealis & 0.1 & 8 & 0.5 & 21 & 0.6 & 17 & 0.1 & 13 \\
\hline & Acer rubrum & 0 & 0 & 0.1 & 4 & 6 & 50 & 6 & 50 & & ssp.longiflora & & & & & & & & \\
\hline & Acer pensylvanicum & 0 & 0 & 0 & 0 & 0.1 & 4 & 0.1 & 4 & & Lonicera canadensis & 0 & 0 & 0.1 & 4 & 0.1 & 8 & 0.1 & 4 \\
\hline & Acer rubrum & 0 & 0 & 0 & 0 & 0.1 & 4 & 0.4 & 13 & & Picea glauca & 0 & 0 & 0.1 & 8 & 0 & 0 & 0 & 0 \\
\hline & Acer saccharum & 0 & 0 & 0 & 0 & 0.6 & 21 & 0.6 & 8 & & Picea rubens & 0.1 & 88 & 0.1 & 79 & 0.2 & 71 & 0.1 & 75 \\
\hline & Acer spicatum & 8 & 8 & 1 & 4 & 0.4 & 13 & 0.4 & 13 & & Prunus pensylvanica & 0.1 & 13 & 0 & 0 & 0.1 & 17 & 0.1 & 4 \\
\hline & Amelanchier spp. & 0.1 & 13 & 0.1 & 13 & 0.3 & 17 & 1 & 25 & & Ribes lacustre & 0.1 & 13 & 0 & 0 & 0 & 0 & 0.1 & 4 \\
\hline & Betula alleghaniensis & 0.8 & 42 & 1 & 29 & 2 & 46 & 5 & 25 & & $\begin{array}{l}\text { Rubus idaeus } \\
\text { ssp.idaeus }\end{array}$ & 0.1 & 8 & 0 & 0 & 0.1 & 4 & 0 & 0 \\
\hline & Betula papyrifera & 1 & 75 & 1 & 63 & 0.2 & 63 & 0.2 & 50 & & Rubus pubescens & 1 & 4 & 0 & 0 & 0.1 & 4 & 0 & 0 \\
\hline & $\begin{array}{l}\text { Corylus cornuta } \\
\text { ssp.cornuta }\end{array}$ & 0 & 0 & 0.1 & 4 & 0 & 0 & 1 & 4 & & $\begin{array}{l}\text { Sambucus racemosa } \\
\text { var.racemosa }\end{array}$ & 0 & 0 & 0.1 & 4 & 0 & 0 & 0.1 & 4 \\
\hline & Lonicera canadensis & 1 & 4 & 0.1 & 4 & 0.1 & 13 & 0 & 0 & & Sorbus decora & 0.2 & 83 & 0.1 & 67 & 0.1 & 50 & 0.1 & 63 \\
\hline & Picea rubens & 0.6 & 8 & 10 & 4 & 0.1 & 4 & 0.1 & 4 & & Gaultheria hispidula & 0 & 0 & 0 & 0 & 0 & 0 & 0.1 & 4 \\
\hline
\end{tabular}




\begin{tabular}{|c|c|c|c|c|c|c|c|c|c|c|c|c|c|c|c|c|c|c|c|}
\hline \multirow{3}{*}{ Layer } & \multirow{3}{*}{ Species } & \multicolumn{8}{|c|}{ Treatments } & \multirow{3}{*}{ Layer } & \multirow{3}{*}{ Species } & \multicolumn{8}{|c|}{ Treatments } \\
\hline & & \multicolumn{2}{|c|}{ Control } & \multicolumn{2}{|c|}{$1.2 \mathrm{~m}$} & \multicolumn{2}{|c|}{$1.8 \mathrm{~m}$} & \multicolumn{2}{|c|}{$2.4 \mathrm{~m}$} & & & \multicolumn{2}{|c|}{ Control } & \multicolumn{2}{|c|}{$1.2 \mathrm{~m}$} & \multicolumn{2}{|c|}{$1.8 \mathrm{~m}$} & \multicolumn{2}{|c|}{$2.4 \mathrm{~m}$} \\
\hline & & Abun. & Freq. & Abun. & Freq. & Abun. & Freq. & Abun. & Freq. & & & Abun. & Freq. & Abun. & Freq. & Abun. & Freq. & Abun. & Freq. \\
\hline \multirow{2}{*}{$\begin{array}{l}\text { Woody Species } \\
(<0.5 \mathrm{~m}-\text { cont. })\end{array}$} & Picea rubens & 0.1 & 4 & 0 & 0 & 0 & 0 & 0 & 0 & \multirow{7}{*}{$\begin{array}{l}\text { Non-Woody } \\
\text { Species (cont.) }\end{array}$} & Phegopteris connectilis & 0.1 & 4 & 0 & 0 & 0 & 0 & 0.1 & 4 \\
\hline & Viburnum lantanoides & 0.1 & 4 & 0 & 0 & 0 & 0 & 0 & 0 & & Polystichum braunii & 0 & 0 & 0 & 0 & 0.1 & 4 & 0 & 0 \\
\hline \multirow{30}{*}{$\begin{array}{l}\text { Non-Woody } \\
\text { Species }\end{array}$} & Poa spp. & 0.1 & 4 & 0 & 0 & 0 & 0 & 0 & 0 & & Pteridium aquilinum & 0 & 0 & 0 & 0 & 0.1 & 8 & 3 & 21 \\
\hline & Aralia nudicaulis & 0.5 & 21 & 0.6 & 42 & 2 & 42 & 3 & 71 & & var.latiuscul & & & & & & & & \\
\hline & $\begin{array}{l}\text { Symphyotrichum } \\
\text { ciliolatum }\end{array}$ & 0.1 & 8 & 0 & 0 & 0.1 & 8 & 0.1 & 8 & & $\begin{array}{l}\text { Thelypteris } \\
\text { noveboracensis }\end{array}$ & 0 & 0 & 0 & 0 & 0 & 0 & 0.1 & 8 \\
\hline & Circaea alpina & 0.1 & 4 & 0 & 0 & 0 & 0 & 0 & 0 & & Carex sp1. & 0.1 & 8 & 0 & 0 & 0 & 0 & 0 & 0 \\
\hline & Clintonia borealis & 2 & 88 & 2 & 92 & 2.2 & 96 & 3 & 96 & & Carex sp2. & 0 & 0 & 0 & 0 & 0 & 0 & 0.1 & 4 \\
\hline & Coptis trifolia & 0.1 & 67 & 0.4 & 79 & 1 & 58 & 0.2 & 54 & \multirow[t]{25}{*}{ Mosses } & Anomodon attenuatus & 0 & 0 & 0 & 0 & 0.1 & 4 & 0 & 0 \\
\hline & Cornus canadensis & 0.3 & 88 & 2 & 100 & 3 & 100 & 1 & 100 & & Aulacomnium palustre & 0.1 & 4 & 0 & 0 & 0 & 0 & 0.1 & 4 \\
\hline & Galium triflorum & 0.1 & 4 & 0 & 0 & 0 & 0 & 0 & 0 & & $\begin{array}{l}\text { Bazzania trilobata } \\
\text { var.trilobata }\end{array}$ & 0.2 & 83 & 0.1 & 92 & 0.2 & 75 & 0.2 & 79 \\
\hline & Goodyera repens & 0.1 & 25 & 0.1 & 46 & 0.1 & 54 & 0.1 & 46 & & Blepharostoma & 0.1 & 25 & 0.1 & 17 & 0.1 & 29 & 0.1 & 13 \\
\hline & Goodyera tesselate & 0.1 & 17 & 0.1 & 17 & 0.1 & 42 & 0.1 & 13 & & trichophyllum ssp.t & & & & & & & & \\
\hline & Goodyera spp. & 0 & 0 & 0.1 & 4 & 0 & 0 & 0 & 0 & & Brachythecium & 0.1 & 83 & 0.1 & 92 & 0.2 & 96 & 0.1 & 83 \\
\hline & Maianthemum & 0.5 & 79 & 0.4 & 67 & 0.5 & 75 & 0.1 & 75 & & acuminatum & & & & & & & & \\
\hline & canadense & & & & & & & & & & Brachythecium & 0.1 & 17 & 0.1 & 38 & 0.1 & 25 & 0.1 & 25 \\
\hline & Mitella nuda & 1 & 4 & 0 & 0 & 0 & 0 & 0 & 0 & & oedipodium & & & & & & & & \\
\hline & Monotropa uniflora & 0.1 & 42 & 0.1 & 33 & 0.1 & 46 & 0.1 & 13 & & $\begin{array}{l}\text { Brachythecium } \\
\text { reflexum var.reflex }\end{array}$ & 0.1 & 4 & 0.1 & 4 & 0 & 0 & 0 & 0 \\
\hline & Orthilia secunda & 0.6 & 8 & 0.1 & 8 & 0 & 0 & 0.1 & 4 & & Brachythecium & 0.1 & 13 & 0.1 & 17 & 0.1 & 4 & 0.1 & 8 \\
\hline & Oxalis montana & 0.5 & 83 & 36 & 83 & 40 & 92 & 42 & 88 & & salebrosum var.sale & & & & & & & & \\
\hline & $\begin{array}{l}\text { Streptopus } \\
\text { amplexifolius }\end{array}$ & 0.1 & 4 & 0 & 0 & 0 & 0 & 0.1 & 4 & & $\begin{array}{l}\text { Callicladium } \\
\text { haldanianum }\end{array}$ & 0.1 & 42 & 0.1 & 29 & 0.1 & 21 & 0.1 & 38 \\
\hline & $\begin{array}{l}\text { Trientalis borealis } \\
\text { ssp.borealis }\end{array}$ & 0.1 & 75 & 0.1 & 83 & 0.1 & 8 & 0.1 & 17 & & $\begin{array}{l}\text { Campylium } \\
\text { chrysophyllum }\end{array}$ & 0.1 & 17 & 0.1 & 8 & 0.1 & 13 & 0.1 & 21 \\
\hline & Trillium spp. & 0.1 & 4 & 0 & 0 & 0.1 & 92 & 0.1 & 88 & & Cephalozia bicuspidata & 0.1 & 96 & 0.1 & 100 & 0.1 & 92 & 0.1 & 96 \\
\hline & Viola renifolia & 0 & 0 & 0 & 0 & 0 & 0 & 0.1 & 4 & & ssp.bicusp & & & & & & & & \\
\hline & Viola spp. & 0.1 & 4 & 0 & 0 & 0 & 0 & 0 & 0 & & $\begin{array}{l}\text { Cephalozia connivens } \\
\text { var.conniven }\end{array}$ & 0.1 & 38 & 0.1 & 33 & 0.1 & 38 & 0.1 & 50 \\
\hline & $\begin{array}{l}\text { Athyrium filix-femina } \\
\text { var.angustu }\end{array}$ & 1 & 4 & 0 & 0 & 0.1 & 4 & 0 & 0 & & Cephalozia lunulifolia & 0.1 & 88 & 0.1 & 88 & 0.1 & 92 & 0.1 & 92 \\
\hline & Dryopteris carthusiana & 0.1 & 4 & 0 & 0 & 2 & 21 & 1 & 4 & & $\begin{array}{l}\text { Cephaloziella rubella } \\
\text { var.rubella }\end{array}$ & 0 & 0 & 0 & 0 & 0.1 & 4 & 0 & 0 \\
\hline & Dryopteris expansa & 5 & 88 & 2 & 92 & 3 & 71 & 3 & 100 & & Dicranum flagellare & 0.1 & 92 & 0.1 & 88 & 0.1 & 88 & 0.1 & 100 \\
\hline & Dryopteris intermedia & 0.4 & 46 & 0.4 & 46 & 2 & 42 & 0.5 & 42 & & Dicranum fuscescens & 0.1 & 100 & 0.1 & 100 & 0.1 & 100 & 0.1 & 100 \\
\hline & Dryopteris spp. & 0.1 & 4 & 0 & 0 & 0 & 0 & 0 & 0 & & var.fuscescen & & & & & & & & \\
\hline & Lycopodium clavatum & 0 & 0 & 0 & 0 & 0 & 0 & 0.1 & 4 & & Dicranella heteromalla & 0.1 & 92 & 0.1 & 79 & 0.1 & 92 & 0.1 & 83 \\
\hline & \multirow{2}{*}{$\begin{array}{l}\text { Lycopodium } \\
\text { dendroideum }\end{array}$} & \multirow[t]{2}{*}{0.1} & \multirow[t]{2}{*}{8} & \multirow[t]{2}{*}{0.1} & 21 & 0.1 & 17 & 0.1 & 17 & & Dicranum montanum & 0.1 & 54 & 0.1 & 42 & 0.1 & 46 & 0.1 & 63 \\
\hline & & & & & & & & & & & Dicranum ontariense & 0.1 & 25 & 0.1 & 13 & 0.1 & 13 & 0.1 & 38 \\
\hline
\end{tabular}




\begin{tabular}{|c|c|c|c|c|c|c|c|c|c|c|c|c|c|c|c|c|c|c|c|}
\hline \multirow{3}{*}{ Layer } & \multirow{3}{*}{ Species } & \multicolumn{8}{|c|}{ Treatments } & \multirow{3}{*}{ Layer } & \multirow{3}{*}{ Species } & \multicolumn{8}{|c|}{ Treatments } \\
\hline & & \multicolumn{2}{|c|}{ Control } & \multicolumn{2}{|c|}{$1.2 \mathrm{~m}$} & \multicolumn{2}{|c|}{$1.8 \mathrm{~m}$} & \multicolumn{2}{|c|}{$2.4 \mathrm{~m}$} & & & \multicolumn{2}{|c|}{ Control } & \multicolumn{2}{|c|}{$1.2 \mathrm{~m}$} & \multicolumn{2}{|c|}{$1.8 \mathrm{~m}$} & \multicolumn{2}{|c|}{$2.4 \mathrm{~m}$} \\
\hline & & Abun. & Freq. & Abun. & Freq. & Abun. & Freq. & Abun. & Freq. & & & Abun. & Freq. & Abun. & Freq. & Abun. & Freq. & Abun. & Freq. \\
\hline \multirow{33}{*}{$\begin{array}{l}\text { Mosses } \\
\text { (cont.) }\end{array}$} & Dicranum polysetum & 0.2 & 79 & 0.3 & 88 & 0.2 & 83 & 0.2 & 83 & \multirow{17}{*}{$\begin{array}{l}\text { Mosses } \\
\text { (cont.) }\end{array}$} & Pohlia nutans & 0.1 & 33 & 0.1 & 67 & 0.1 & 58 & 0.1 & 54 \\
\hline & $\begin{array}{l}\text { Eurhynchium } \\
\text { pulchellum var.pulche }\end{array}$ & 0.1 & 21 & 0.1 & 17 & 0.1 & 21 & 0.1 & 13 & & $\begin{array}{l}\text { Polytrichum commune } \\
\text { var.commune }\end{array}$ & 0.1 & 17 & 0.1 & 25 & 0.1 & 25 & 0.1 & 21 \\
\hline & Frullania spp. & 0.1 & 4 & 0 & 0 & 0.1 & 4 & 0 & 0 & & Polytrichum formosum & 0 & 0 & 0.1 & 4 & 0 & 0 & 0 & 0 \\
\hline & Geocalyx graveolens & 0.1 & 33 & 0.1 & 25 & 0.1 & 38 & 0.1 & 29 & & Polytrichum & 0.1 & 17 & 0.1 & 8 & 0.1 & 17 & 0.1 & 17 \\
\hline & Harpanthus & 0.1 & 4 & 0.1 & 4 & 0.1 & 4 & 0 & 0 & & juniperinum & & & & & & & & \\
\hline & drummondii & & & & & & & & & & Polytrichum ohioense & 0.1 & 42 & 0.1 & 25 & 0.1 & 38 & 0.1 & 58 \\
\hline & Heterocladium & 0.1 & 4 & 0 & 0 & 0 & 0 & 0 & 0 & & Ptilidium ciliare & 0 & 0 & 0 & 0 & 0 & 0 & 0.1 & 4 \\
\hline & $\begin{array}{l}\text { dimorphum } \\
\text { Hylocomium splendens }\end{array}$ & 13 & 79 & 14 & 83 & 16 & 79 & 9 & 75 & & $\begin{array}{l}\text { Ptilium crista- } \\
\text { castrensis }\end{array}$ & 0.2 & 100 & 0.3 & 100 & 0.2 & 92 & 0.2 & 96 \\
\hline & Hypnum cupressiforme & 0 & 0 & 0 & 0 & 0.1 & 4 & 0 & 0 & & Ptilidium pulcherrimum & 0.1 & 100 & 0.1 & 100 & 0.1 & 100 & 0.1 & 100 \\
\hline & var.cupressi & & & & & & & & & & Radula complanata & 0 & 0 & 0 & 0 & 0 & 0 & 0.1 & 4 \\
\hline & Hypnum imponens & 0.1 & 88 & 0.1 & 100 & 0.1 & 83 & 0.1 & 79 & & Sanionia uncinata & 0.1 & 75 & 0.1 & 50 & 0.1 & 75 & 0.1 & 75 \\
\hline & $\begin{array}{l}\text { Hypnum pallescens } \\
\text { var.pallescens }\end{array}$ & 0.1 & 96 & 0.1 & 92 & 0.1 & 75 & 0.1 & 88 & & Sphagnum capillifolium & 0.1 & 13 & 0.6 & 8 & 0.1 & 17 & 0 & 0 \\
\hline & Hypnum pratense & 0.1 & 33 & 0.1 & 33 & 0.1 & 42 & 0.1 & 25 & & Sphagnum girgensohnii & 0.1 & 13 & 0.1 & 13 & 0.1 & 4 & 0.1 & 4 \\
\hline & $\begin{array}{l}\text { Jamesoniella } \\
\text { autumnalis var.autum }\end{array}$ & 0.1 & 46 & 0.1 & 50 & 0.1 & 67 & 0.1 & 71 & & $\begin{array}{l}\text { Sphagnum } \\
\text { magellanicum }\end{array}$ & 0 & 0 & 0.1 & 4 & 0 & 0 & 0 & 0 \\
\hline & Lepidozia reptans & 0 & 0 & 0.1 & 4 & 0 & 0 & 0 & 0 & & Steerecleus serrulatus & 0.1 & 17 & 0 & 0 & 0.1 & 21 & 0.1 & 21 \\
\hline & Loeskeobryum & 1 & 67 & 3 & 50 & 0.7 & 75 & 1 & 88 & & Tetraphis pellucida & 0.1 & 96 & 0.1 & 100 & 0.1 & 96 & 0.1 & 100 \\
\hline & brevirostre & 1 & & & 0 & & & & & & Thuidium delicatulum & 0.1 & 21 & 0 & 0 & 0.1 & 8 & 0 & 0 \\
\hline & Lophozia badensis & 0 & 0 & 0 & 0 & 0.1 & 4 & 0 & 0 & \multirow[t]{16}{*}{ Lichens } & Biatora vernalis & 0.1 & 13 & 0.1 & 17 & 0.1 & 13 & 0.1 & 13 \\
\hline & var.badensis & & & & & & & & & & Candelaria concolor & 0.1 & 83 & 0.1 & 75 & 0.1 & 83 & 0.1 & 71 \\
\hline & Lophozia bicrenata & 0.1 & 63 & 0.1 & 63 & 0.1 & 58 & 0.1 & 71 & & Cladonia cenotea & 0.1 & 33 & 0.1 & 29 & 0.1 & 46 & 0.1 & 38 \\
\hline & Lophozia capitata & 0.1 & 8 & 0.1 & 17 & 0.1 & 8 & 0.1 & 4 & & Cladonia chlorophaea & 0.1 & 17 & 0.1 & 21 & 0.1 & 21 & 0.1 & 21 \\
\hline & $\begin{array}{l}\text { Lophozia heterocolpos } \\
\text { var.heteroc }\end{array}$ & 0.1 & 13 & 0.1 & 8 & 0.1 & 25 & 0 & 0 & & Cladonia coniocraea & 0.1 & 100 & 0.1 & 96 & 0.1 & 96 & 0.1 & 96 \\
\hline & Lophocolea & 0.1 & 79 & 0.1 & 100 & 0.1 & 83 & 0.1 & 92 & & Cladonia cornuta & 0.1 & 4 & 0 & 0 & 0 & 0 & 0 & 0 \\
\hline & heterophylla & & & & & & & & & & Cladonia crispata & 0.1 & 8 & 0.1 & 8 & 0.1 & 8 & 0.1 & 25 \\
\hline & Nowellia curvifolia & 0.1 & 29 & 0.1 & 38 & 0.1 & 17 & 0.1 & 17 & & var.crispata & & & & & & & & \\
\hline & Oncophorus & 0 & 0 & 0.1 & 4 & 0 & 0 & 0 & 0 & & Cladonia cristatella & 0 & 0 & 0 & 0 & 0.1 & 8 & 0.1 & 4 \\
\hline & wahlenbergii & & & & & & & & & & Cladonia deformis & 0.1 & 4 & 0 & 0 & 0.1 & 4 & 0 & 0 \\
\hline & Plagiothecium & 0.1 & 4 & 0.1 & 4 & 0.1 & 17 & 0.1 & 8 & & Cladonia digitata & 0 & 0 & 0.1 & 4 & 0 & 0 & 0 & 0 \\
\hline & denticulatum & & & & & & & & & & Cladonia fimbriata & 0.1 & 79 & 0.1 & 79 & 0.1 & 92 & 0.1 & 92 \\
\hline & Plagiothecium laetum & 0.1 & 100 & 0.1 & 100 & 0.1 & 100 & 0.1 & 100 & & Cladonia gracilis & 0.1 & 4 & 0 & 0 & 0 & 0 & 0.1 & 8 \\
\hline & Plagiomnium medium & 0 & 0 & 0 & 0 & 0.1 & 4 & 0.1 & 4 & & ssp.turbinata & & & & & & & & \\
\hline & var.medium & & & & & & & & & & Cladina mitis & 0 & 0 & 0.1 & 4 & 0 & 0 & 0 & 0 \\
\hline & Platygyrium repens & 0.1 & 88 & 0.1 & 79 & 0.1 & 88 & 0.1 & 92 & & Cladonia multiformis & 0 & 0 & 0.1 & 4 & 0.1 & 8 & 0.1 & 4 \\
\hline
\end{tabular}




\begin{tabular}{|c|c|c|c|c|c|c|c|c|c|c|c|c|c|c|c|c|c|c|c|}
\hline \multirow{3}{*}{ Layer } & \multirow{3}{*}{ Species } & \multicolumn{8}{|c|}{ Treatments } & \multirow{3}{*}{ Layer } & \multirow{3}{*}{ Species } & \multicolumn{8}{|c|}{ Treatments } \\
\hline & & \multicolumn{2}{|c|}{ Control } & \multicolumn{2}{|c|}{$1.2 \mathrm{~m}$} & \multicolumn{2}{|c|}{$1.8 \mathrm{~m}$} & \multicolumn{2}{|c|}{$2.4 \mathrm{~m}$} & & & \multicolumn{2}{|c|}{ Control } & \multicolumn{2}{|c|}{$1.2 \mathrm{~m}$} & \multicolumn{2}{|c|}{$1.8 \mathrm{~m}$} & \multicolumn{2}{|c|}{$2.4 \mathrm{~m}$} \\
\hline & & Abun. & Freq. & Abun. & Freq. & Abun. & Freq. & Abun. & Freq. & & & Abun. & Freq. & Abun. & Freq. & Abun. & Freq. & Abun. & Freq. \\
\hline \multirow{19}{*}{$\begin{array}{l}\text { Lichens } \\
\text { (cont.) }\end{array}$} & Cladonia pleurota & 0.1 & 21 & 0.1 & 38 & 0.1 & 29 & 0.1 & 8 & & \multirow{2}{*}{$\begin{array}{l}\text { Peltigera } \\
\text { neopolydactyla }\end{array}$} & \multirow[t]{2}{*}{0.1} & \multirow[t]{2}{*}{25} & \multirow[t]{2}{*}{0.1} & \multirow[t]{2}{*}{8} & \multirow[t]{2}{*}{0.1} & \multirow[t]{2}{*}{25} & \multirow[t]{2}{*}{0.1} & \multirow[t]{2}{*}{29} \\
\hline & Cladonia pyxidata & 0.1 & 4 & 0.1 & 4 & 0.1 & 4 & 0 & 0 & & & & & & & & & & \\
\hline & Cladina rangiferina & 0.1 & 25 & 0.1 & 42 & 0.1 & 21 & 0.1 & 29 & & \multirow{2}{*}{$\begin{array}{l}\text { Pertusaria amara } \\
\text { Phaeophyscia adiastola }\end{array}$} & \multirow{2}{*}{$\begin{array}{c}0.1 \\
0\end{array}$} & \multirow{2}{*}{$\begin{array}{c}21 \\
0\end{array}$} & \multirow{2}{*}{$\begin{array}{c}0.1 \\
0\end{array}$} & 25 & 0.1 & 4 & 0.1 & 4 \\
\hline & Cladonia squamosa & 0.1 & 21 & 0.1 & 29 & 0.1 & 29 & 0.1 & 21 & & & & & & & 0.1 & 4 & 0 & 0 \\
\hline & Leproloma & 0 & 0 & 0 & 0 & 0 & 0 & 0.1 & 8 & & Phaeophyscia ciliata & 0.1 & 4 & 0 & 0 & 0 & 0 & 0 & 0 \\
\hline & membranaceum & & & & & & & & & & Platismatia glauca & 0.1 & 92 & 0.1 & 96 & 0.1 & 92 & 0.1 & 96 \\
\hline & Evernia mesomorpha & 0.1 & 42 & 0.1 & 54 & 0.1 & 38 & 0.1 & 25 & & Phlyctis argena & 0 & 0 & 0 & 0 & 0 & 0 & 0.1 & 4 \\
\hline & Hypogymnia bitteri & 0.1 & 4 & 0 & 0 & 0 & 0 & 0 & 0 & & Physconia muscigena & 0 & 0 & 0 & 0 & 0 & 0 & 0.1 & 13 \\
\hline & Hypgymnia krogiae & 0 & 0 & 0 & 0 & 0.1 & 4 & 0 & 0 & & Ramalina americana & 0 & 0 & 0 & 0 & 0.1 & 4 & 0.1 & 8 \\
\hline & Hypogymnia physodes & 0.1 & 79 & 0.1 & 67 & 0.1 & 83 & 0.1 & 100 & & Ramalina dilacerata & 0.1 & 8 & 0.1 & 8 & 0.1 & 4 & 0.1 & 4 \\
\hline & Icmadophila ericetorum & 0.1 & 4 & 0.1 & 13 & 0.1 & 8 & 0.1 & 8 & & Trapeliopsis granulosa & 0.1 & 4 & 0.1 & 4 & 0 & 0 & 0 & 0 \\
\hline & Lecanora hybocarpa & 0 & 0 & 0.1 & 4 & 0 & 0 & 0 & 0 & & Tuckermannopsis & 0.1 & 8 & 0 & 0 & 0.1 & 17 & 0.1 & 17 \\
\hline & Lepraria lobificans & 0.1 & 83 & 0.1 & 88 & 0.1 & 88 & 0.1 & 79 & & americana & & & & & & & & \\
\hline & Loxospora pustulata & 0.1 & 4 & 0 & 0 & 0 & 0 & 0 & 0 & & $\begin{array}{l}\text { Tuckermannopsis } \\
\text { orbata }\end{array}$ & 0.1 & 4 & 0.1 & 33 & 0.1 & 33 & 0.1 & 38 \\
\hline & $\begin{array}{l}\text { Mycoblastus } \\
\text { sanguinarius }\end{array}$ & 0.1 & 88 & 0.1 & 96 & 0.1 & 92 & 0.1 & 100 & & Tuckermannopsis spp & 0 & 0 & 0.1 & 4 & 0.1 & 4 & 0.1 & 4 \\
\hline & Pannaria rubiginosa & 0 & 0 & 0 & 0 & 0.1 & 4 & 0 & 0 & & Usnea filipendula & 0.1 & 88 & 0.1 & 92 & 0.1 & 100 & 0.1 & 96 \\
\hline & Parmelia saxatilis & 0.1 & 4 & 0 & 0 & 0 & 0 & 0 & 0 & & Usnea lapponica & 0 & 0 & 0 & 0 & 0.1 & 4 & 0 & 0 \\
\hline & Parmelia sulcata & 0.1 & 63 & 0.1 & 67 & 0.1 & 75 & 0.1 & 71 & & Usnea spp. & 0 & 0 & 0.1 & 4 & 0 & 0 & 0 & 0 \\
\hline & & & & & & & & & & & $\begin{array}{l}\text { Xanthoparmelia } \\
\text { somloënsis }\end{array}$ & 0 & 0 & 0.1 & 4 & 0 & 0 & 0 & 0 \\
\hline
\end{tabular}

